\title{
KESESUAIAN LAHAN DAN POTENSI PRODUKSI TANAMAN GAMBIR DI KABUPATEN PESISIR SELATAN SUMATERA BARAT
}

\author{
Juniarti, Y. Rasyid , D. Fiantis \\ Jurusan Tanah Faperta Unand Padang
}

\begin{abstract}
The land suitability study for gambir crop (Uncaria gambir, Roxb) in the buffer zone of the National Park of Kerinci Seblat (Taman Nasional Kerinci Seblat) at Salido Saribulan, sub district IV Jurai, Pesisir Selatan was investigated. The objective of this study was to estimate the land suitability for gambir in Salido Saribulan. The soils were sampled in composite ways for analyses in laboratory. The results showed that according to climatic and physical land condition, the studied area was considered as class S1 (highly suitable). However, based on land suitability class, it was grouped as S3f (marginally suitable with some constraints in the availability of soil nutrients). We suggested that to increase gambir production in the studied area can be done by adding some fertilizers both organic and inorganic ones.
\end{abstract}

Kata Kunci: land suitability, gambir plant, portensial production

\section{PENDAHULUAN}

Kebutuhan informasi/data sumber daya lahan untuk perencanaan pembangunan adalah sangat penting. Sumberdaya lahan merupakan salah satu faktor fisik utama untuk dipertimbangkan dalam perencanaan, penyusunan dan pelaksanaan tata ruang terutama di daratan. Pengalaman dari berbagai wilayah, ternyata banyak menimbulkan masalah fisik pada lahan yang akhirnya berakibat buruk kepada kehidupan sosial dan ekonomi masyarakat. Oleh sebab itu peran data sumberdaya lahan menjadi penting dan harus diperhatikan dalam penggunaan dan pemakaian lahan.

Kesesuaian lahan yang dibahas dalam penelitian ini adalah tanaman Gambir (Uncaria gambir, Roxb) yang diharapkan potensial untuk dikembangkan di daerah sekitar kawasan penyangga TNKS (Taman Nasional Kerinci Seblat) Salido Saribulan, Kecamatan IV Jurai, Pesisir Selatan. Gambir merupakan getah atau sari daun dan ranting yang dikeringkan dari tanaman gambir (Nazir, 2000). Dalam dunia perdagangan gambir dikenal dengan nama Kateku kuning, Kacu, Terra, Cutch.
Kegunaan gambir antara lain untuk: bahan baku obat-obatan dan kosmetik, penyamak kulit, pewarna tekstil, bahan cat, pembuatan bir dan ramuan dalam Luas areal pertanaman Gambir di Sumbar meningkat rata-rata $8 \%$ per tahun dan sampai tahun 1998 produksinya meningkat pula sebanyak $17 \%$ per tahun. Akan tetapi pada tahun 1999, pertambahan luas areal tidak diikuti dengan peningkatan produksi (Dinas Perkebunan Sumbar, 2000). menyirih (Bakhtiar, 1991 dan Suherdi, 1993).

Gambir merupakan komoditas ekspor spesifik Sumatera Barat. Luas areal pertanaman Gambir di Sumbar meningkat rata-rata $8 \%$ per tahun dan sampai tahun 1998 produksinya meningkat pula sebanyak $17 \%$ per tahun. Akan tetapi pada tahun 1999, pertambahan luas areal tidak diikuti dengan peningkatan produksi (Dinas Perkebunan Sumbar, 2000). Dalam lima tahun terakhir ini volume ekspor meningkat sebesar $82,81 \%$ sedangkan nilai ekspornya mencapai US \$2,5/kg (Denian, Zulkifli dan Taher, 2000). Dengan demikian komoditas ini mempunyai nilai yang sangat strategis bagi pendapatan daerah. 
Hal ini diduga bahwa salah satu penyebabnya adalah penggunaan lahan yang tidak sesuai. Karena ketidaksesuaian peruntukan lahan yang tidak sesuai dengan daya dukungnya tersebut dapat mengakibatkan sumber daya lahan tidak dapat dimanfaatkan secara berkelanjutan.

Untuk mengevaluasi kesesuaian lahan digunakan model kuantitatif dari FAO yang memadukan data lingkungan, iklim dan kondisi tanah (sifat fisika dan kimia tanah) (Sys et all, 1991). Setiap data diberi penilaian (rating) tersendiri dan dimasukkan ke dalam beberapa rumus matematika sehingga akhirnya didapatkan potensi produksi suatu lahan berdasarkan iklim (Climatic Production Potential $=\mathrm{CPP})$ secara kuantitatif. Dengan memasukkan data produksi tanaman yang sebenarnya model ini akan dapat memprediksi produksi tanaman yang sebenarnya dari suatu lahan (Land Production Potential = LPP $)($ Sys et all, 1991). Adanya program modeling ini, akan lebih memudahkan untuk menyusun program perencanaan oleh pemerintah daerah dan petani di daerah ini. Dengan mengganti beberapa variabel tertentu dari program modeling ini, dapat juga memprediksi hasil tanaman pada daerah lain (Fiantis, 2001).

Tujuan penelitian ini adalah untuk menilai tingkat kesesuaian lahan di daerah sekitar kawasan penyangga TNKS sehingga didapatkan wilayah yang sesuai untuk pengembangan komoditi tanaman Gambir.

\section{BAHAN DAN METODA}

Penelitian terdiri dari dua tahap yaitu :

(1) studi kepustakaan, pengumpulan data primer yaitu data produksi melalui wawancara dengan petani dan data sekunder berupa penelaahan bahanbahan referensi dari laporan yang ada.

survey dan pengambilan contoh tanah di lapangan

Pemilihan lokasi pengambilan contoh tanah berdasarkan informasi yang didapat dari peta geologi (Gambar 1), peta lereng (Gambar 2 ), peta tanah daerah penelitian
(Gambar 3). Untuk survey dan pengambilan contoh digunakan alat-alat standar ke lapangan seperti bor, cangkul, parang, meteran, GPS (Geographical Positioning Satellite), Munsell Soil Color Chart, kantong plastikl, ring sampel dan lain-lainnya yang dianggap perlu. Alat yang digunakan di labor adalah sesuai dengan analisis yang akan dilakukan.

Di lapangan akan diamati lingkungan dan morfologi tanah dengan cara pembuatan profil tanah dan pemboran. Contoh tanah akan diambil contoh tanah komposit untuk analisis kimia tanah dan contoh tanah tak terganggu untuk sifat fisika tanah.

\section{Analisis Tanah di Laboratorium}

Pengamatan sifat dan ciri tanah meliputi: Analisis C-organik tanah menggunakan metode Walkey and Black (Walkey, 1947 cit Tan, 1996). Analisis $\mathrm{N}$ total tanah dengan metode Kjeldahl (Mulvaney, 1982 cit Page, Miller and Keeney, 1982). Analisis P total dan $\mathrm{P}$ tersedia tanah, $\mathrm{P}$ total dengan menggunakan metode Pengabuan Kering (Sudjadi, Wijik dan Soleh, 1971) dan P tersedia dengan metode Bray II (Olsen and Sommers, 1982 cit Page et al, 1982). Analisis pH tanah dengan metode Elektrometrik $\mathrm{pH}$ meter elektroda.KTK dengan metode pencucian Ammonium Asetat $1 \mathrm{~N}$ pH 7 begitu pula dengan penetapan Kation Basa.

\section{Analisis SIG dalam Pembuatan Peta Tanah}

Analisis geografi ini akan dilaksanakan dengan menggunakan suatu perangkat lunak SIG (Mapinfo, ArcInfo). Dalam hal ini, kemampuan analitikal berupa fungsi-fungsi analisis perangkat lunak tersebut digunakan bagi menghasilkan berbagai bentuk informasi yang diinginkan.

\section{Analisa Penilaian Kesesuaian Lahan Tanaman Gambir (Interpretasi Data)}

Data yang didapatkan diinterpretasikan dengan membandingkan karakteristik lahan dengan produksi tanaman gambir yang dihasilkan.berdasarkan kondisi tanah yang ada dengan produksi gambir. 

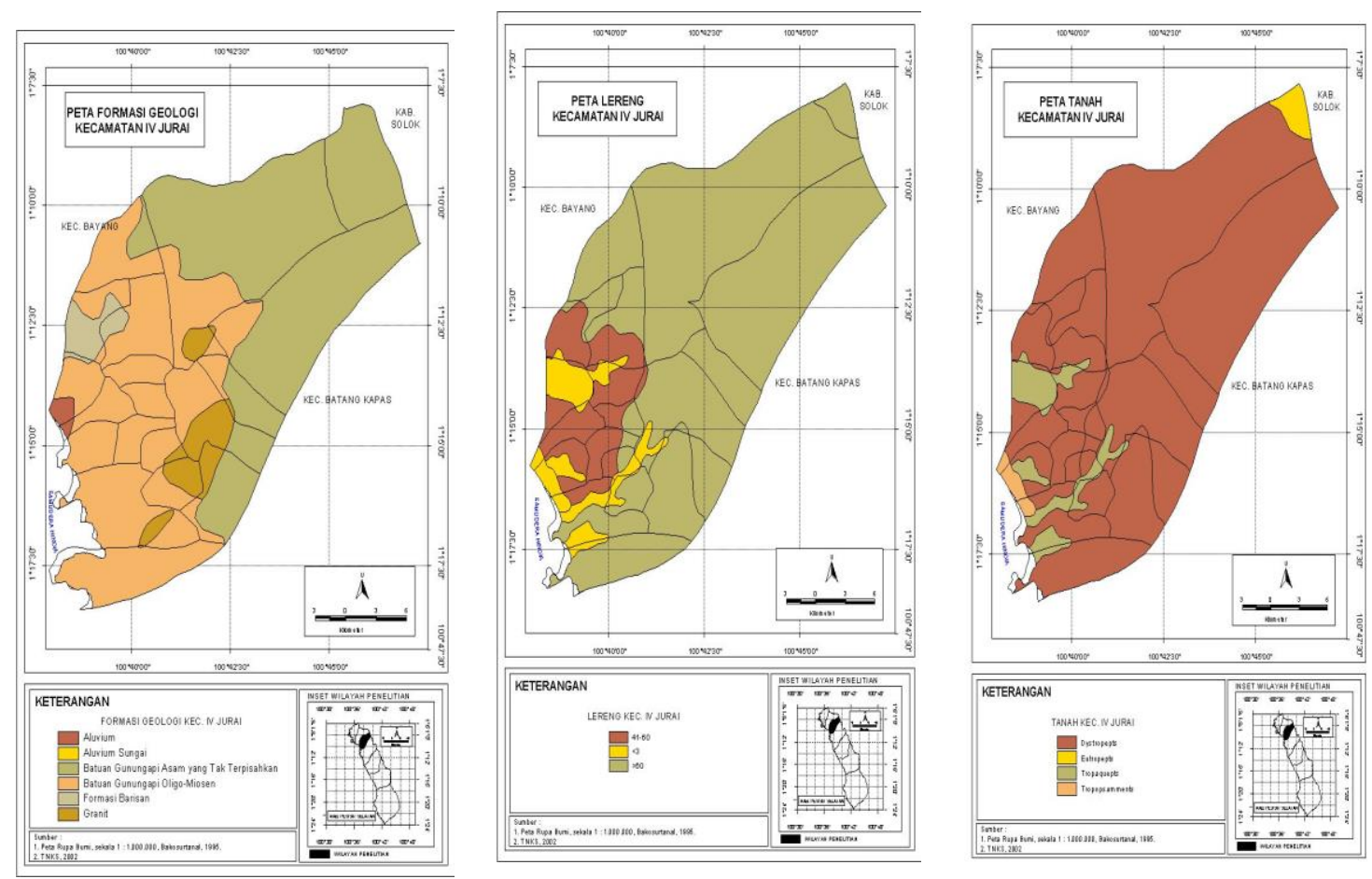

Gambar 1. Peta Geologi Pessel Gambar 2. Peta Lereng Pessel Gambar 3. Peta Tanah Pessel

Penilaian kesesuaian lahan dilakukan pada tingkat semi detail dengan skala peta 1:50.000. Pada kategori semi detail ini diperlukan data yang terdiri atas:

(1) Data iklim yaitu rata-rata jam penyinaran matahari (n, jam/hari); rata-rata suhu udara maksimum $\left(\mathrm{T}_{\max }{ }^{\circ} \mathrm{C}\right)$, rata-rata suhu udara minimum $\left(\mathrm{T}_{\min }{ }^{\circ} \mathrm{C}\right)$; rata-rata humiditas harian ( $\mathrm{RH}, \%)$; rata-rata kecepatan angin $\left(\mathrm{U}, \mathrm{ms}^{-1}\right.$ and $\mathrm{m}$ hari $\left.{ }^{-1}\right)$. Total hujan bulanan (P, mm), dan jumlah hari hujan (RD)

(2) Data lingkungan tanah seperti drainase tanah; kedalaman efektif tanah, periode banjir, kemiringan lahan, batu di permukaan (Rock outcrop);

(3)Data karakteristik tanah yaitu KTK, pH, N total, $\mathrm{P}_{2} \mathrm{O}_{5}$ tersedia, $\mathrm{K}_{2} \mathrm{O}$ tersedia, salinitasi, kejenuhan alumunium, struktur, konsistensi.

\section{Penetuan Radiation thermal Production Potential (RPP)}

Untuk menentukan RPP ini dipakai data produksi biomasa bersih yang di dapatkan dengan rumus matematika berikut:

$\mathrm{RPP}=\mathrm{Bn} \times \mathrm{Hi}$ atau

$\mathrm{RPP}=\frac{0,26 \times \text { bgm } \times \mathrm{KLAI} \times \mathrm{Hi}}{\frac{1}{2}+(0,25 \div \mathrm{ct})}$

$\operatorname{bgm}=f x b o+(I-f) x b c$

$\mathrm{f}=$ fraction of the day time that sky is overcast

bo = Maximum gross biomass production on overcast days

$\mathrm{bc}=$ Maximum gross biomass production on clear days

$\mathrm{Hi}=$ Harvest indeks (indeks panen)

$\mathrm{RPP}=\mathrm{Bn} \times \mathrm{Hi}$

atau

$\mathrm{RPP}=\frac{0,26 \times \text { bgm } \times \mathrm{KLAI} \times \mathrm{Hi}}{\frac{1}{2}+(0,25 \div \mathrm{ct})}$

$\operatorname{bgm}=f x b o+(I-f) x b c$

$\mathrm{f} \quad=$ fraction of the day time that sky is overcast 
bo $=$ Maximum gross biomass production on overcast days

$\mathrm{bc}=$ Maximum gross biomass production on clear days

$\mathrm{Hi}=$ Harvest indeks (indeks panen)

Hasil perhitungan RPP diatas akan diintegrasikan kedalam Program GIS (Geographical Information System) dengan menggunakan program ArcInfo ataupun MapInfo.

\section{Penentuan Climatic Production Pontetal (CPP)}

Penghitungan CPP dimulai dengan menghitung parameter-parameter dibawah ini (Van Ranst, 1991):

(i) Evapotranspirasi dari tanaman referensi (ETo);

(ii) Evapotranspirasi aero $\left(\mathrm{ET}_{\text {aero }}\right)$

(iii) Evapotranspirasi radiasi (ET ${ }_{\mathrm{rad}}$ )

(iv) Evapotranspirasi maximum $\left(\mathrm{ET}_{\max }\right)$

(v) Koefesien tanaman ( $\mathrm{kc}=$ crop coefficient)

(vi) Total ketersediaan air (Sa), yaitu jumlah air antara kapasitas lapang dan titik layu permanen;

(vii) Curah hujan-efectif ( $\left.\mathrm{P}_{\text {eff }}\right)$;

Rumus untuk menghitung CPP adalah

$\mathrm{CCP}=\mathrm{RPP}\left[1-\mathrm{ky}\left(1-\mathrm{ET}_{\mathrm{a}}\right) / \mathrm{ET}_{\max }\right]$,

Dimana ky adalah faktor respon panen dan $\mathrm{ET}_{\mathrm{a}}$ adalah evapotranspirasi sebenarnya (actual evapotranspiration).

\section{Penentuan Land Production Pontential (LPP)}

LPP dihitung setelah didapatkan nilai CPP dengan memperhatikan indeks data tanah (Sy) dan indeks pengelolaan lahan (My), dengan rumus:

$$
\mathrm{LPP}=\mathrm{CPP} \times \mathrm{My} \times \mathrm{Sy} \text {; }
$$

Dimana My $=\mathrm{Ya} /\left(\mathrm{CPP} \times \mathrm{Sy}_{\mathrm{p}}\right)$,

dan $\mathrm{Ya}=$ Produksi tanaman di lapangan (kg/ha);

serta $S y_{p}=$ indeks tanah yang didapatkan dari rumus pendekatan secara parametric; sedangkan My diperoleh dari tabel yang dikeluarkan FAO tentang rating pengelolaan suatu lahan.

\section{HASIL DAN PEMBAHASAN}

\section{Evaluasi Keadaan Iklim untuk Pertumbuhan dan Produksi Gambir di Salido Saribulan}

Berdasarkan data iklim maka tanah di lokasi penelitian dapat digolongkan kepada lahan yang berpotensi untuk pengembangan tanaman gambir. Potensi air untuk kebutuhan tanaman gambir termasuk sangat cukup, temperatur udara sesuai sehingga ordo kesesuaian lahan berdasarkan data iklim adalah sangat sesuai (S1). Presipitasi pada daerah Salido Saribulan lebih besar bila dibandingkan dengan potensial evapotranspirasi menurut Papadakis, hal ini dapat dilihat pada Gambar 4, dengan demikian terjadi surplus air dan tidak terdapat bulan kering yang nyata sepanjang tahun. Dengan curah hujan yang merata ini maka ketersediaan air mencukupi untuk pertumbuhan tanaman gambir. Air merupakan pelarut unsur-unsur hara di dalam tanah, dengan bantuan air unsur hara tersebut menjadi tersedia bagi tanaman. Sebaliknya bila kekurangan air, akar tanaman sukar untuk menyerap unsur hara dari dalam tanah, yang berakibat pada musim kemarau yang berkepanjangan, sehingga akan menyebabkan produksi tanaman menurun (Fiantis, 2001).

Sementara hasil kalkulasi besarnya evapotranspirasi untuk tanaman referensi $\left(\mathrm{ET}_{0}\right)$ dengan menggunakan metoda Dorenbos and Pruitt (1977), ternyata lebih tinggi bila dibandingkan dengan nilai PET dengan menggunakan metoda Papadakis. Perbedaan ini dikarenakan Papadakis memperhitungkan jumlah presipitasi dan suhu udara rata-rata dan maksimum, sedangkan Dorenbos and Pruit menambahkan beberapa parameter lain seperti kelembaban udara relatif, kecepatan angin, lamanya penyinaran matahari, panjang hari dan radiasi seperti hasil penelitian yang dilaporkan oleh Fiantis (2001) bahwa besarnya evapotranspirasi 
untuk tanaman referensi kelapa sawit $\left(\mathrm{ET}_{0}\right)$ harian dengan mengunakan metoda Dorenbos and Pruit (1977) berkisar antara $3.23-8.58$ $\mathrm{mm}$ dan bulanan antara $100.14-257.56 \mathrm{~mm}$ lebih tinggi bila dibandingkan dengan nilai PET dengan menggunakan metoda Papadakis

Selanjutnya dari hasil kalkulasi parameter iklim yang terdiri dari presipitasi, suhu udara maksimum, suhu udara minimum dan suhu udara rata-rata, lamanya penyinaran matahari dan panjang hari, kecepatan angin dan kelembaban udara, maka potensi produksi tanaman gambir berdasarkan iklim adalah termasuk kelas sesuai (S), terlihat dari hasil perhitungan CPP dan LPP tanaman Gambir pada Tabel 1 dan 2. Sedangkan data spasial dari RPP, CPP dan LPP di lokasi penelitian disajikan pada Gambar 5, 6 dan 7.

Dari Tabel 1 dan 2 terlihat bahwa lahan di lokasi penelitian daerah Salido Saribulan sangat sesuai bila dikembangkan untuk tanaman gambir. Hal ini dapat diketahui dari hasil pengamatan karakteristik lahan dan perhitungan indeks lahan dengan produksi tanaman gambir yang dihasilkan (produksi sebenarnya) di lapangan memberikan nilai produksi yang tidak jauh berbeda setelah dilakukan perhitungan CPP dan LPP tanaman gambir di lokasi penelitian Salido Saribulan. Dengan demikian dari hasil penelitian tersebut maka daerah lokasi penelitian Salido
Saribulan dapat dikelompokkan sesuai untuk pengembangan tanaman gambir, karena adanya faktor pendukung produksi tanaman gambir yang optimum di daerah tersebut yaitu kondisi kesuburan tanah dan iklim yang sesuai.

Dari Gambar 5 dan 6 terlihat bahwa nilai RPP dan CPP pada lokasi panelitian di daerah Salido Saribulan memiliki nilai yang berbeda walaupun daerah tersebut mempunyai keragaman yang sama. Nilai RPP sebesar 5 ton/Ha di lokasi penelitian lebih tinggi dibandingkan dengan nilai $\mathrm{CPP}$ yaitu sebesar 3.7 ton/Ha. Nilai RPP 5 ton/Ha merupakan produksi gambir ideal yang nilainya dipengaruhi oleh radiasi matahari yaitu lamanya penyinaran, sehingga dengan kondisi iklim yang terdapat di lokasi penelitian daerah Salido Saribulan seharusnya produksi gambir yang dihasilkan mencapai 5 ton/Ha. Sedangkan nilai CPP yang lebih rendah yaitu 3.7 ton/Ha merupakan produksi gambir di lapangan yang dipengaruhi oleh curah hujan di lokasi penelitian daerah Salido Saribulan. Hal ini menunjukkan bahwa produksi gambir di lapangan di pengaruhi oleh iklim terutama lamanya penyinaran dan curah hujan yang akan mempengaruhi berlangsungnya proses fotosintesis tanaman gambir.

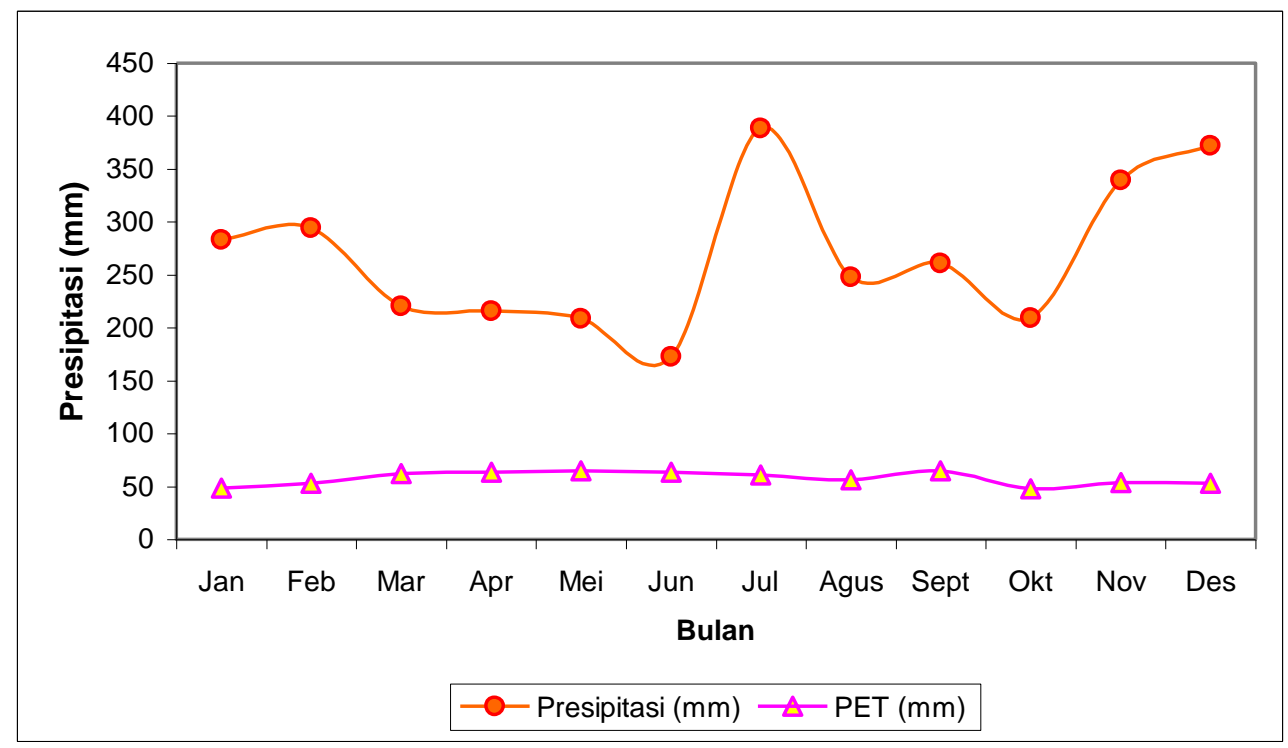

Gambar 4. Potensial Evapotranspirasi (PET) menurut Papadakis untuk daerah Pesisir Selatan 
Tabel. 1. Nilai Climatic Production Potential (CPP) dan Land Production Potential (LPP) Gambir per bulan pada daerah Pessel

\begin{tabular}{|c|c|c|c|c|c|r|}
\hline Sampel & $\begin{array}{c}\text { Produksi } \\
\text { sebenarnya } \\
(\mathrm{Ton} / \mathrm{Ha})\end{array}$ & $\begin{array}{c}\text { RPP } \\
(\mathrm{Ton} / \mathrm{Ha})\end{array}$ & $\begin{array}{c}\mathrm{CPP} \\
(\mathrm{Ton} / \mathrm{Ha})\end{array}$ & $\begin{array}{c}\text { Indeks } \\
\text { Manajemen } \\
(\mathrm{My})\end{array}$ & $\begin{array}{c}\text { Indeks } \\
\text { Tanah (Sy) }\end{array}$ & LPP (Ton/Ha) \\
\hline I & 6 & 5 & 3,7 & 0,67 & 0,5 & 1,2395 \\
\hline II & 3 & 5 & 3,7 & 0,38 & 0,5 & 0,703 \\
\hline III & 3 & 5 & 3,7 & 0,47 & 0,5 & 0,8695 \\
\hline
\end{tabular}

Tabel 2. Nilai Climatic Production Potential (CPP) dan Land Production Potential (LPP) Gambir per tahun pada daerah Pessel

\begin{tabular}{|c|c|c|c|c|c|c|}
\hline Sampel & $\begin{array}{c}\text { Produksi } \\
\text { sebenarnya } \\
(\text { Ton/Ha) }\end{array}$ & $\begin{array}{c}\text { RPP } \\
(\text { Ton/Ha) }\end{array}$ & $\begin{array}{c}\text { CPP } \\
(\text { Ton/Ha) }\end{array}$ & $\begin{array}{c}\text { Indeks } \\
\text { Manajemen } \\
(\mathrm{My})\end{array}$ & $\begin{array}{c}\text { Indeks } \\
\text { Tanah (Sy) }\end{array}$ & LPP (Ton/Ha) \\
\hline I & 72 & 60 & 44,4 & 8,04 & 6 & 2141,856 \\
\hline II & 36 & 60 & 44,4 & 4,56 & 6 & 1214,784 \\
\hline III & 36 & 60 & 44,4 & 5,64 & 6 & 1502,496 \\
\hline
\end{tabular}

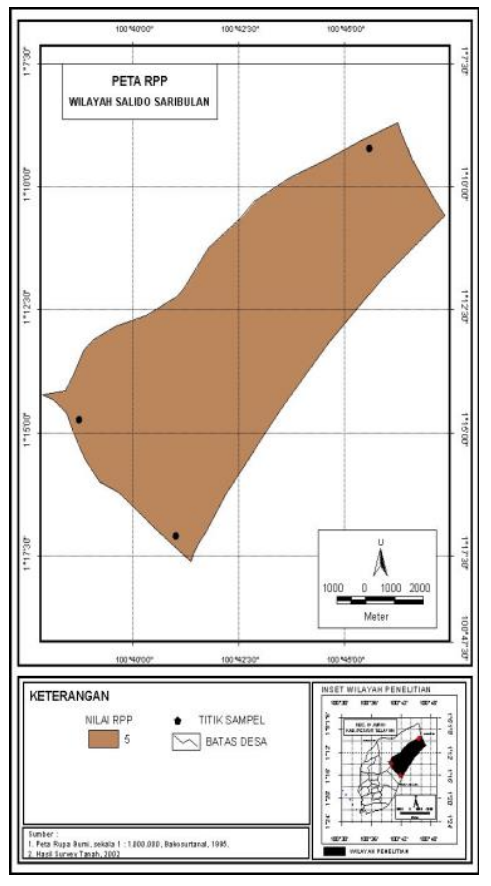

Gambar 5. Data spasial RPP Salido Saribulan

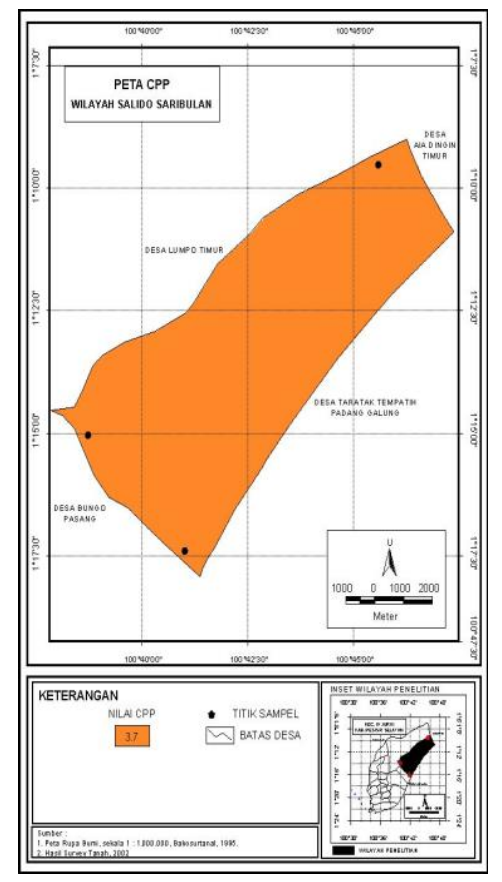

Gambar 6. Data spasial CPP Salido Saribulan

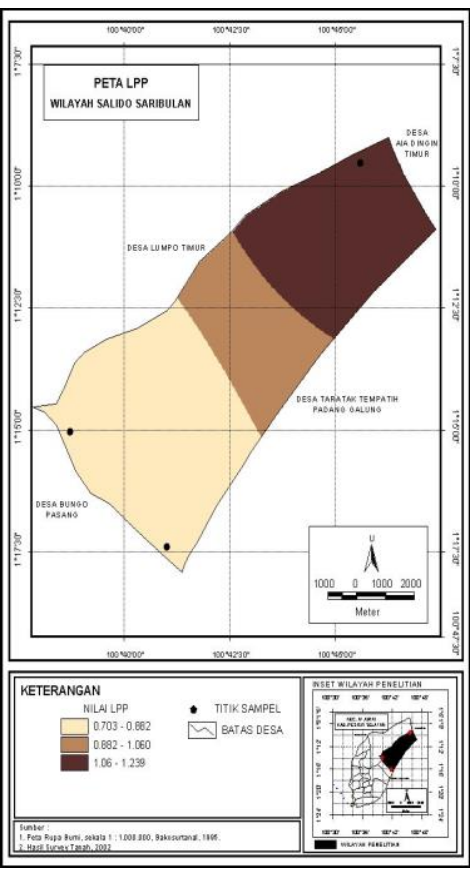

Gambar 7. Data spasial LPP Salido Saribulan 
Selanjutnya dari Gambar 7 terlihat bahwa adanya perbedaan nilai LPP di lokasi penelitian daerah Salido Saribulan yaitu berkisar antara $0.703-1.239$ ton/Ha lebih rendah dibandingkan dengan nilai RPP dan CPP. Nilai LPP tersebut merupakan produksi gambir sebenarnya yang dihasilkan di lapangan. Perbedaan ini disebabkan karena selain faktor iklim produksi tanamam gambir juga dipengaruhi oleh faktor pengelolaan dan tanah. Terlihat bahwa pada daerah lereng yang ditanami gambir nilai LPP jauh lebih tinggi dibandingkan dengan daerah kaki lereng yang diusahakan untuk persawahan.

\section{Iubungan Kondisi Fisik Lahan dengan Kesuburan Tanah dan Produksi Gambir}

Bentuk lahan pada lokasi penelitian merupakan tipe fisiografi perbukitan, yaitu sistem lahan dengan kelerengan yang sangat curam (>60\%) (Gambar 2). Menurut Desaunettes (1977) kelerengan yang tinggi menyebabkan aliran permukaan dan erosi yang besar. Sehingga atas dasar pertimbangan resiko, lahan ini secara umum tidak dianjurkan untuk dibuka sebagai lahan pertanian. Lahan dengan lereng antara $16-$ $45 \%$ hanya dianjurkan untuk tanaman permanen seperti perkebunan tanaman keras dan kehutanan. Sedangkan lahan dengan lereng $>60 \%$ dibiarkan hutan. Akan tetapi khusus untuk tanaman gambir yang banyak dijumpai pada fisiografi perbukitan ini, dipertimbangkan sesuai (S) dengan syarat harus melakukan usaha konservasi tanah.

Batuan induk dan bentuk wilayah mempengaruhi proses pembentukan tanah di lokasi penelitian, dengan demikian juga akan mempengaruhi kesuburan tanahnya. Selanjutnya berdasarkan hasil pengamatan di lapangan tanah di lokasi penelitian mempunyai tekstur liat, masam, miskin hara dan kation basa, kandungan bahan organik dan KTK tanah rendah. hasil analisis sifat kimia tanah berdasarkan topografi daerah yaitu lereng bawah dan kaki bukit dapat dilihat pada Tabel 3.
Berdasarkan data yang ditampilkan pada Tabel 3. perbedaan sifat tanah akibat perbedaan topografi dicirikan olehhasil analisis mempunyai kisaran yang sama yaitu $\mathrm{pH}$ tanah masam, kandungan $\mathrm{C}$-organik sedang, $\mathrm{N}$ - total sedang, KTK rendah dan kation basa.

Kondisi kemasaman tanah $(\mathrm{pH})$ termasuk kriteria masam baik pada lereng bawah maupun kaki bukit, namun terlihat peningkatan ke bagian kaki bukit Peningkatan $\mathrm{pH}$ tanah pada bagian kaki bukit ini diduga akibat erosi yang terjadi pada bagian lereng bawah, sehingga menyebabkan $\mathrm{pH}$ tanah menjadi rendah. Demikian juga halnya dengan kandungan $\mathrm{C}$ organik dan kation basa serta kandungan unsur hara lainnya yaitu lebih rendah di bagian lereng, sebagaimana juga dilaporkan hasil penelitian Husnain (2000) terhadap kesuburan tanah menunjukkan bahwa bagian lereng memiliki kandungan hara terendah terutama bahan organik dan kation basa dibandingkan bagian kaki bukit. Rendahnya kandungan hara di bagian lereng ini disebabkan erosi yang tinggi akibat lereng yang tajam $(40-47 \%)$. Hal ini sesuai dengan pendapat Graham dan Buol (1990) bahwa kandungan basa-basa dipengaruhi oleh topografi dan drainase, dimana daerah kaki bukit adalah daerah terakumulasinya basa-basa. Penurunan kandungan bahan organik di bagian lereng akan menyebabkan penurunan KTK tanah pada bagian lereng di lokasi penelitian.

Tanah di lokasi penelitian diklasifikasikan menurut sistem Taksonomi Tanah (Soil Survey Staf, 1987) ke dalam ordo Inceptisol. Jenis tanah ini mempunyai horizon bawah kambik yang dicirikan dengan adanya perubahan warna atau struktur tanah sehingga memerlukan penanganan berbeda agar tidak dijumpai kendala-kendala dalam pengelolaan tanah dan pemilihan jenis komoditas yang akan dikembangkan. 
Klasifikasi kesesuaian iklim dan penilaian kesesuaian lahan untuk tanaman gambir di daerah sekitar kawasan penyangga TNKS Salido Saribulan dapat dilihat pada Tabel 4.

Dari Tabel 4. dapat dilihat bahwa hasil pengamatan klasifikasi kesesuaian iklim untuk tanaman gambir di Salido Saribulan terhadap parameter iklim berdasarkan Storie Method dan Square Root Method bahwa daerah penelitian memiliki indeks iklim dengan rating 75/78. Hal ini menunjukkan bahwa iklim di lokasi penelitian bila dibandingkan dengan syarat tumbuh tanaman gambir adalah sangat sesuai untuk tanaman gambir, kelas iklimnya termasuk S1. Unsur iklim yang mendukung adalah presipitasi, suhu udara rata-rata, suhu udara maksimum.

Selain faktor iklim, penilaian kesesuaian lahan untuk tanaman gambir di Salido Saribulan juga dilakukan. Hasil penilaian tersebut dapat dilihat pada Tabel 5.

Hasil penilaian kesesuaian lahan untuk tanaman gambir berdasarkan Storie Method dan Square Root Method memiliki rating 30 dan 49.
Berdasarkan kriteria kelas kesesuaian lahan maka daerah penelitian termasuk kedalam kelas kesesuaian lahan S3f dengan faktor pembatas berat. Faktor pembatas adalah retensi hara dan hara tersedia yaitu KTK serta unsur hara N. Sebagai alternatif pemecahannya perlu dilakukan penambahan unsur hara berupa pemberian pupuk dan penambahan bahan organik. Menurut laporan Biro Pusat Statistik (2001) produksi gambir yang dihasilkan hanya 6 ton/Ha. Hasil ini ternyata jauh di bawah produksi gambir yang dihasilkan di daerah Mahat yaitu sebesar 30 ton/Ha (Saidi dan Berd, 2001). Perbedaan hasil ini disebabkan karena di Kanagarian Mahat Kabupaten Limapuluh Kota telah lama diusahakan budidaya tanaman gambir dibandingkan dengan daerah Salido Saribulan. Selain itu bila dilihat dari segi kesuburan tanahnya daerah penelitian tergolong rendah memiliki $\mathrm{pH}$ tanah berkisar antara 4,53 - 4,7. Sedangkan kemasaman tanah pada daerah Mahat berkisar antara 4,8 - 5,0 dengan kandungan $\mathrm{N}$ total $0,49-0,15 \%$. Data spasial dari $\mathrm{pH}$ tanah di daerah penelitian tersebut disajikan pada Gambar 8.

Tabel 3. Kandungan hara tanah pada 2 tempat pengambilan sampel yang diambil pada kedalaman 0-60 cm

\begin{tabular}{|l|ll|ll|}
\hline Sifat kimia tanah & \multicolumn{2}{|l|}{ Lereng bawah* } & \multicolumn{2}{|l|}{ Kaki bukit* } \\
\hline pH & 4.6 & $\mathrm{~m}$ & 4.75 & $\mathrm{~m}$ \\
C-organik (\%) & 2.8 & $\mathrm{~s}$ & 3.89 & $\mathrm{~s}$ \\
N- total (\%) & 0.25 & $\mathrm{~s}$ & 0.27 & $\mathrm{~s}$ \\
P- tersedia (ppm) & 7 & $\mathrm{sr}$ & 9 & $\mathrm{sr}$ \\
KTK (me/100 g) & 13.46 & $\mathrm{r}$ & 14.29 & $\mathrm{r}$ \\
$\mathrm{KB}(\%)$ & 14.94 & $\mathrm{sr}$ & 16.23 & $\mathrm{sr}$ \\
$\mathrm{K}(\mathrm{me} / 100 \mathrm{~g})$ & 0.29 & $\mathrm{r}$ & 0.35 & $\mathrm{~s}$ \\
$\mathrm{Na}(\mathrm{me} / 100 \mathrm{~g})$ & 1.11 & $\mathrm{~s}$ & 1.18 & $\mathrm{~s}$ \\
$\mathrm{Ca}(\mathrm{me} / 100 \mathrm{~g})$ & 0.28 & $\mathrm{sr}$ & 0.32 & $\mathrm{sr}$ \\
$\mathrm{Mg}(\mathrm{me} / 100 \mathrm{~g})$ & 0.33 & $\mathrm{r}$ & 0.47 & $\mathrm{r}$ \\
\hline
\end{tabular}

$* \mathrm{~m}=$ masam, $\mathrm{sr}=$ sangat rendah, $\mathrm{r}=$ rendah, $\mathrm{s}=$ sedang 
Tabel 4. Klasifikasi Kesesuaian Iklim untuk tanaman gambir di Salido Saribulan

\begin{tabular}{|c|l|l|c|c|c|}
\hline Sim & \multicolumn{1}{|c|}{ Parameter Iklim } & \multicolumn{1}{|c|}{ Nilai } & Kelas & Level Limit & Rating \\
\hline C & Curah hujan (mm) & 3214.12 & S1 & 0 & 100 \\
\hline C & Suhu Rata-rata & 27.54 & S1 & 0 & 100 \\
\hline C & Suhu maksimum & 30.7 & S1 & 0 & 100 \\
\hline C & Suhu minimum & 24.37 & S1 & 0 & 100 \\
C & n/N & 0.51 & S1 & 1 & 85 \\
\hline & Indeks Iklim & Storie Method/SquareRoot Method & $75 / 78$ \\
& Rating Iklim & Storie Method/SquareRoot Method & $85 / 92$ \\
\hline & Kelas Iklim & \multicolumn{5}{|l}{ S1/S1 } & S1 \\
\hline
\end{tabular}

Tabel 5. Penilaian Kesesuaian Lahan untuk tanaman gambir di Salido Saribulan

\begin{tabular}{|c|l|c|c|c|c|}
\hline Sim & \multicolumn{1}{|c|}{ Parameter Lahan } & Nilai & Kelas & Level Limit & Rating \\
\hline T & Lereng (\%) & 25 & S1 & 0 & 100 \\
\hline W & Bahaya banjir & 0 & S1 & 0 & 100 \\
& Drainase & Well-drained & S1 & 1 & 100 \\
\hline \multirow{2}{*}{ S } & Tekstur/struktur & 120 & S1 & 1 & 100 \\
& Kedalaman tanah (cm) & 13.46 & S3 & 3 & 100 \\
\hline \multirow{2}{*}{ F } & KTK (me/100 g) & 4.6 & S1 & 0 & 100 \\
& pH & 2.8 & S2 & 2 & 80 \\
& N-total & Storie Method/SquareRoot Method & $30 / 49$ \\
\hline & Indeks Lahan & \multicolumn{3}{|l}{ S3f } & \\
\hline
\end{tabular}




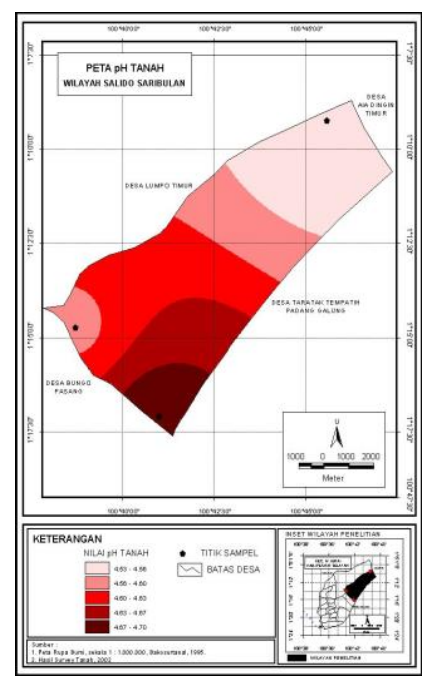

Gambar 8. Data spasial pH tanah Salido Saribulan

Dari Gambar 8. terlihat bahwa nilai $\mathrm{pH}$ tanah di lokasi penelitian memiliki perbedaan, pada daerah kaki lereng $\mathrm{pH}$ tanah berkisar antara 4,67 - 4,7 yang meliputi daerah seluas $900 \mathrm{Ha}$ lebih tinggi dibandingkan dengan daerah lereng yang berkisar antara 4,53-4,56 dengan daerah seluas $400 \mathrm{Ha}$. Hal ini disebabkan karena perbedaan topografi (kondisi fisik lahan) dan pengelolaan tanahnya. Pada daerah lereng yang ditanami gambir sering terjadi erosi, karena tajuk tanaman yang kecil hal ini mengakibatkan terjadinya penurunan $\mathrm{pH}$ tanah dibandingkan dengan daerah kaki lereng. Selain itu pada daerah kaki lereng telah diusahakan dengan pembukaan sawah yang telah pernah dilakukan tindakan pemupukan, hal ini menyebabkan $\mathrm{pH}$ tanah lebih tinggi dibandingkan dengan daerah lereng.

Sementara itu P tersedia pada lokasi penelitian berkisar antara 7,0 - 9,0 dan KTK tanah di lokasi penelitian berkisar antara 13,46 - 18,08 yang tergolong rendah meliputi daerah seluas $2000 \mathrm{Ha}$. Kondisi kesuburan tanah di lokasi penelitian yang rendah ini berbeda jauh bila dibandingkan dengan daerah

Dengan melahirkan perhitungan nilai RPP, CPP dan LPP maka didapat basis data yang diharapkan dapat digunakan pada daerah lain di Sumatera Barat dan di Indonesia pada umumnya guna menyusun rencana tata guna lahan yang tepat untuk memperoleh produksi pertanian khususnya gambir. Pada daerah-daerah yang mempunyai iklim dan kondisi kesuburan tanah yang sama dengan lokasi penelitian dengan hanya menukarkan parameterparameter yang ada pada model sesuai dengan keadaan tanah dan lingkungan daerah tersebut.

Mahat yang memiliki $\mathrm{pH}$ tanah berkisar antara 4,8-5, P tersedia berkisar antara $8-$ 16 ppm yang tergolong sedang - sangat tingi dan KTK tanah berkisar antara $17-24$ me/100 g yang tergolong sedang (Saidi dan Berd, 2001). Kenyataan ini menunjukkan bahwa produksi gambir di daerah penelitian masih bisa terus ditingkatkan dengan cara penambahan unsur hara agar dapat meningkatkan nilai indeks lahannya.

Untuk peningkatan indeks lahan menjadi $>50$ dan kelas kesesuaian menjadi S1 (Sangat sesuai) di masa yang akan datang dapat dilakukan dengan perbaikan usaha manajemen/pengelolaan budidaya pertanian melalui tindakan pemupukan, sehingga diharapkan produksi gambir yang dihasilkan nantinya akan meningkat.

\section{KESIMPULAN DAN SARAN}

Daerah Salido Saribulan termasuk ke dalam kelas kesesuaian lahan S3f yaitu sesuai untuk pengembangan tanaman gambir dengan faktor pembatas retensi hara. Potensi produksi gambir aktual di daerah Salido Saribulan 5 ton/Ha lebih tinggi dibandingkan dengan produksi gambir sebenarnya.

\section{Ucapan Terima Kasih}

Penulis menyampaikan ucapan terima kasih kepada Direktur Jendral Pendidikan Tinggi Departemen Pendidikan Nasional dan Pemerintah Daerah Pesisir Selatan yang telah memberikan dana untuk penelitian ini. Terima kasih yang sama juga disampaikan kepada Bapak Sugeng Nugroho, Ssi. atas bantuan dan saran selama penelitian. 


\section{DAFTAR PUSTAKA}

Bakhtiar, A. 1991. Manfaat gambir. Makalah penataran petani dan pedagang pengumpul gambir di kecamatan Pangkalan kabupaten 50 Kota tanggal 29 - 30. November 1991. FMIPA Unand. Padang. 23 Hal.

Bappeda. 2000. Rencana program pengembangan kawasan andalan Padang Pariaman dan sekitarnya. Badan Perencanaan Pembangunan Daerah Provinsi Sumatera Barat bekerjasama dengan PT. Arsi Wastuadi dan PT. Seruni Cipta. 135 Hal.

CSR/FAO Staff. 1983. Reconnaissance Land Resource Surveys 1 : 250.000 Scale. Atlas Format Procedures. AGOF/INS/78/006 Manual 4 version1 CSR Bogor. Ministry of Agriculture Government on Indonesia.

Denian, A; Zulkifli, H dan A. Taher. 2000. Status dan perkembangan penelitian tanaman gambir. Makalah seminar sehari teknik budidaya dan pengolahan hasil gambir dan nilam. BPTP Sukarami Solok. 24 Januari 2000. 20 Hal.

Desaunttes, J.R. 1977. Catalogue of landformfor Indonesia. FAO dan Soil Research Institute Ministry of Agriculture. Jakarta.

Dinas Perkebunan Sumatera Barat. 2000. Statistik perkebunan daerah Sumatera Barat. Dinas Perkebunan Propinsi Sumatera Barat. Padang. $216 \mathrm{Hal}$
Fiantis, D. 2001. Pengembangan Sistem Informasi Geogafi tanah vulkanis Sumatera Barat untuk peningkatan produksi tanaman hortikultura. Proposal Riset Unggulan Terpadu IX . Universitas Andalas. Padang. 13 Hal.

Graham, R.C. and S.W.Buol. 1990. Soil Geomorphic Relation on the Blue Ridge front: II Soil Characteristic and Pedogenesis. Soil Sci. Soc. Am. J. 54: 1367-1377.

Husnain. 2000. Tinjauan status hara tanaman berdasarkan sekuen topografi di daerah Tanjung Alai Kabupaten Solok. Tesis. Program Pascasarjana Universitas Andalas Padang. 77 Hal.

Nazir, N. 2000. Gambir. Budidaya, pengolahan dan prospek diversifikasinya. Yayasan Hutanku. Yayasan Hasil Hutan Non-Kayu. Padang. 138 Hal.

Saidi, A dan Isril Berd. 2001. Tanah-tanah pertanaman gambir di Sumatera Barat. Fakultas Pertanian Universitas Andalas dan PK-PLP Unand. $15 \mathrm{Hal}$

Sys, C; Evan Ranst and J. Debaveye. 1991. Land Evaluation part I. Principles in land evaluation and crop production calculations. ITC for post graduate soil scientist state university of ghent Berghium. 